\title{
"The effect of loan granted factor on peer-to-peer lending (funded loan) in Indonesia"
}

\begin{tabular}{|c|c|}
\hline AUTHORS & $\begin{array}{l}\text { Fajri Kurniawan (D https://orcid.org/0000-0001-8987-8626 } \\
\text { Chandra Wijaya (D https://orcid.org/0000-0001-9313-8823 }\end{array}$ \\
\hline ARTICLE INFO & $\begin{array}{l}\text { Fajri Kurniawan and Chandra Wijaya (2020). The effect of loan granted factor on } \\
\text { peer-to-peer lending (funded loan) in Indonesia. Investment Management and } \\
\text { Financial Innovations, 17(4), 165-174. doi:10.21511/imfi.17(4).2020.16 }\end{array}$ \\
\hline DOI & http://dx.doi.org/10.21511/imfi.17(4).2020.16 \\
\hline RELEASED ON & Tuesday, 01 December 2020 \\
\hline RECEIVED ON & Friday, 22 May 2020 \\
\hline ACCEPTED ON & Tuesday, 17 November 2020 \\
\hline LICENSE & $\begin{array}{l}(c)) \text { EY } \\
\text { This work is licensed under a Creative Commons Attribution } 4.0 \text { International } \\
\text { License }\end{array}$ \\
\hline JOURNAL & "Investment Management and Financial Innovations" \\
\hline ISSN PRINT & $1810-4967$ \\
\hline ISSN ONLINE & $1812-9358$ \\
\hline PUBLISHER & LLC "Consulting Publishing Company "Business Perspectives" \\
\hline FOUNDER & LLC "Consulting Publishing Company "Business Perspectives" \\
\hline$\sigma^{\circ}$ & $\begin{array}{l}\text { ニここ } \\
\text { 三ニこ }\end{array}$ \\
\hline NUMBER OF REFERENCES & NUMBER OF FIGURES \\
\hline 23 & 3 \\
\hline
\end{tabular}

(c) The author(s) 2021. This publication is an open access article. 


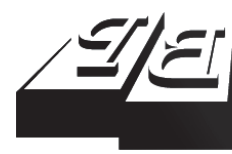

BUSINESS PERSPECTIVES

(O)

LLC "CPC "Business Perspectives" Hryhorii Skovoroda lane, 10, Sumy, 40022, Ukraine www.businessperspectives.org
Received on: $22^{\text {nd }}$ of May, 2020 Accepted on: $17^{\text {th }}$ of November, 2020 Published on: $1^{\text {st }}$ of December, 2020

(C) Fajri Kurniawan,

Chandra Wijaya, 2020

Fajri Kurniawan, Bachelor, Researcher, Faculty of Administrative Science, Department of Business Administration, Universitas Indonesia, Indonesia.

Chandra Wijaya, Doctor, Professor, Faculty of Administrative Science, Department of Business Administration, Universitas Indonesia, Indonesia. (Corresponding author)

\title{
THE EFFECT OF LOAN GRANTED FACTOR ON PEER-TO-PEER LENDING (FUNDED LOAN) IN INDONESIA
}

\begin{abstract}
This study aims to determine whether the loan granted factor can affect peer-to-peer lending in Indonesia. The factors investigated in this research are the loan amount, loan period, interest rate, gender, and loan history using the data from registered and licensed peer-to-peer lending by the Financial Services Authority or Otoritas Jasa Keuangan (OJK) on November 2019. By examining 1,006 loans, the analytical method used is binary logistic regression with a significance level of alpha 0.05 . The results of this research are loan amount, loan period, and loan history have the strongest impact on borrowers' loan funding decision, suggesting that these loan characteristics can signal information that standard measures are used for loan funding. However, interest rate and gender have no significant effect on loan granted. Overall, loan funding decisions are based on proper and relevant signals given by loan characteristics.
\end{abstract}

Keywords

JEL Classification

\section{INTRODUCTION}

In this era, the internet and technology continue to develop over time. Technological developments encourage industry to continue to innovate and adapt to current conditions. The increasingly widespread technological developments make it easier for people to carry out various daily activities, including in the financial sector. The emergence of financial technology in the financial sector makes it easy for all types of transactions, including borrowing. With the advent of financial technology (fintech), previously conventional finance has begun to shift. The increasingly advanced developments in the financial sector led to progress in terms of borrowing money. However, not all financial companies that apply fintech have been registered.

Currently, of 127 registered fintech companies, only 13 are licensed fintech entities, eight of which are fintech lenders by Otoritas Jasa Keuangan [Financial Services Authority] (OJK), the supervisor of financial services in Indonesia. The difference between licensed fintech and registered fintech is that licensed fintech must have ISO 27001, international standard certification in the application of information security management. The problem that occurs in society is generally a sense of distrust when borrowing money using technology. However, the emergence of licensed fintech could increase public confidence in peer-to-peer lending fintech. Increasing borrowers' trust in lenders and an increasing number of supervised fintech companies could increase lending to the public. The increase in transaction volume will 
also continue to increase in line with the fintech industry's development. With the development and growth of online lending, it is necessary to explore the factors that affect whether a loan is given in full or in part. Borrowers can consider these data when assessing the likelihood of obtaining a loan in full or not (Mach et al., 2014).

Therefore, there are several alternative roles proposed by OJK. First, the OJK can play a role in overseeing and reviewing all electronic fintech lending contracts with the consumer so that electronic contracts are expected to have implications for the realization of justice for both parties. Second, the OJK immediately establish an alternative institution for fintech dispute resolution online to facilitate both parties to settle disputes effectively and efficiently. Third, in the context of the enactment of the personal data protection law, as a preventive measure, the OJK can coordinate in exercising their authority in the context of legal protection for fintech lending provides who violate the right to privacy of personal data both in the center and the regions (Priskarini et al., 2019).

The Indonesian Joint Funding Fintech Association, an association that manages peer-to-peer lending regulations, stated that access to borrower data by peer-to-peer lending service providers is currently limited to peer-to-peer lending, which is useful for analyzing creditworthiness. Before access was restricted, peer-to-peer lenders could access 15 information variables about loans and borrowers. There are fifteen variables regarding borrowers data, namely the borrower's saving habits, loan size, borrower's perception of the repayment period, sources of income, availability of training, business experience, type of business, family size, saving purpose, income, loan size received, experience, and ethnicity, loan interest, total filing fee, and installment amount. Now they can only access three information variables, namely camera, microphone, and location. Boundaries will reduce the borrower's ability to analyze, affecting loan funding decisions (Asnawi \& Wijaya, 2005).

Limited access to assessments for loan applications on the platform providers and investors' side results in asymmetric information. Information about borrowers is important to do. Lack of information indirectly increases the risk of default (Lin et al., 2017). To avoid asymmetric information, fintech lending platforms must collect borrower characteristics data on their platforms. Better data help potential investors analyze their borrowers' characteristics and the selection errors of investments in their portfolios (Napitupulu et al., 2017).

In contrast to the limitations of the analysis of the characteristics of loans and borrowers by OJK, the development of peer-to-peer lending has continued to increase. In contrast to the study results of Mach et al. (2014), the increase in total usage coupled with the standardized scoring system for peer-topeer lending has grown substantially since its inception in 2007 and shows no signs of slowing down. Unfortunately, in Indonesia, there is no such system. Although borrowers use some limited variables to lend money, the number and total transactions continue to increase.

Since 7 September 2019, Indonesia has 127 fintech entities registered in OJK. Forty new fintech companies were registered with the OJK in 2019. In July 2019, there were 32,971,425 transactions, an increase of $275 \%$ from the previous year. The accumulation of loans in all online loans in Indonesia reached IDR 27 trillion, or 141\%, for six months from December 2018 to July 2019 (OJK, 2019). This shows an increase in online transactions, especially in the field of online lending. This increase is expected to increase loans with low default risk on online loan platforms in Indonesia.

This period was chosen because data were available on the platform during data collection. The sample chosen is all peer-to-peer lending transactions from the lending market. Based on this background, the researcher is interested in examining the influence of loan granted factors on peer-to-peer lending in Indonesia. The factors referred to include loan amount, loan period, interest rate, gender, and loan history. 


\section{LITERATURE REVIEW}

Peer-to-peer (P2P) lending can be defined as a "financial exchange" that occurs directly between individuals without direct intermediation of a traditional financial institution (Omarini, 2018). The development of fintech, especially in online lending, is currently developing rapidly in Indonesia. However, this has not been followed by the development of researches on the topic. Research on fintech is now widely carried out in countries that have adopted it first, such as China.

Zhang et al. (2017) aimed to determine what factors influence a loan being granted or not in peerto-peer transactions lending in China. Their research was motivated by the development and challenges of the peer-to-peer lending market. Besides, Zhang et al. (2017) stated that the industry has high risks and high returns and that the number of lenders is increasing rapidly and facing various problems in practice. Firstly, there are high default rate and high industry risks. Secondly, many investors blindly seek high returns and follow suit in investment. Thirdly, most platforms lack rapid and effective credit ranking and loan approval system.

This study analyzes the factors that influence whether borrowers obtain loans in full through peer-to-peer lending in China, improving the quality of the loan approval process and reducing operational risk. Using data from Paipaidai, this paper assesses 43,837 loans from January to June 2014. This study distinguishes influence factors into four groups, including basic information, loan information, credit information, social information, loan characteristics, and borrower characteristics and twenty-two variables. The results of this study indicate that the variable of interest rate, repayment period, description, credit grade, successful loan number, failed loan number, gender, and the borrower's credit score are significant on loan granted factors on the Paipaidai platform.

Mach et al. (2014) observed the characteristics of granted loans employed from LendingClub.com. The data include borrower characteristics, loan status granted, and loan details. The data consisted of just under 100,000 loans granted and 670,000 loans that were rejected.
The study examined loan-level by looking at characteristics of granted and non-granted loan applications and then take a more in-depth look at granted applications (Mach et al., 2014). The employed variables included business profile, year, employment, housing price index, FICO credit scores. Their research was motivated by distrust and dissatisfaction with banks in the global financial crisis in 2008-2009. The emergence of peer-to-peer lending involves groups and individuals in providing funding. Therefore, small businesses often have personal relationships with lenders after obtaining business funding. It could increase lender trust, which can be useful if there is further funding by the small businesses. The results indicated that the borrower's business profile and loan interest rates have significance on loan approval.

Kgoroeadira et al. (2019) examined whether a business profile influences a loan to be granted. Another purpose of the study was to determine what factors influence the interest rates of a loan. Kgoroeadira et al. (2019) classified business profiles through several industries: construction, transportation, services, retail and trade, manufacturing, wholesale, agriculture, finance, and real estate. Besides, two other variables assessed were time and region. The variables used to determine the level of loans are credit grade, homeownership, income range, employment status, and existing firm or business profile. The method used by Kgoroeadira et al. (2019) was Tobit regression. The results indicate that home ownership, credit grade, employee status, and income have significance for lender decisions (Kgoroeadira et al., 2019).

Nowak et al. (2018) determined small businesses' ability to show creditworthiness using text descriptions in the online peer-to-peer lending market. Specifically, the authors analyzed the relationship between written that small business loan descriptions and whether investors grant a loan or not. The background of their research was the increase in loans granted through peerto-peer lending, which allows borrowers to bypass banks and work with lenders personally. The peer-to-peer lending marketplace has now effectively created a credit marketplace between borrowers and lenders outside the bank's require- 
ments. The variables used in this study were loan amount, loan period, interest rate, installment, income, debt-to-income ratio, and FICO score. The analytical method used was Tobit regression, and results indicated that loans with low FICO scores can still influence lender investment decisions through descriptions made in the marketplace (Nowak et al., 2018).

A loan or credit is a trust of the owner of a fund to pay a sum of funds with the expectation of a future return (Suiter \& Thomas, 1938). If a company gets funding in the form of a loan, some of the funds are lent by a financial institution, and the company is obliged to return it within the agreed period through installments, including the principal and interest on the loan.

Fintech has various interpretations from several sources as the industry develops. Fintech can be simplified as a financial service for both banks and non-banks with the adaptation of technology. Kim et al. (2016) describe fintech as a service sector that uses mobile-based technology and information to improve the existing financial system's efficiency. Fintech provides several services, one of which is peer-to-peer lending.

Peer-to-peer lending is an activity between individuals on a fintech platform where no intermediary is needed (Bachmann et al., 2011). The loan process is determined directly between the borrower and lender when interacting on a website provided by a peer-to-peer lending service provider. Peer-to-peer lending was first introduced in the United States in 2005 through a platform called Zopa. Loans are obligations of one party to pay funds to another party under agreed terms, whether written or oral. These obligations have implications for the obligation to repay a certain amount of funds within a predetermined period (Fabozzi, 2006).

Lin et al. (2013) analyze the relationship between online friendships and transactional outcomes on the P2P market. Hypothesized borrowers with friends are more likely to have their loan requests granted. This research assumed that these loans have lower interest rates. Hard credit information, auction characteristics, variables about group and borrowers friendship ties are the var- iables in this research. Data sources used in this study are from Prosper.com (Lin et al., 2013).

The study finds that borrowers with online friends on the Prosper.com platform have better ex-ante outcomes. The results are consistent with the joint hypothesis that friendship ties act as a signal of credit quality and that individual investors understand this relationship and incorporate it into their lending decisions. This research finds that borrowers with friends, especially those that are more likely to be credible signals of credit quality, are less likely to default.

Zhang et al. (2017) revealed that the loan amount has a relationship with the loan approval. The result showed that the lower a loan, the more likely it is granted (Zhang et al., 2017). Determining the loan period in providing loans is essential. The loan period, or payback period, is the repayment length that is a component of interest rate calculations. The loan period is the borrower's promise to return the loan at an agreed time (Crosson \& Needles, 2008).

The interest rate is the amount of funds paid to the lender based on the percentage of the total loan agreed upon in return for the loan given (Merton, 1974). Interest rate is one component that must be considered by prospective lenders compared to the loan amount (Edelberg, 2006). Debt structures and fluctuations in the value of assets will affect the interest rate and the loan default rate (Merton, 1974).

Gender also refers to the economic, social, political, cultural, and opportunity conditions associated with men and women. These values can change at any time according to time and conditions. Gender conceptualization can be described as a relationship in social institutions (West \& Zimmerman, 1987). Gender is important to be considered as an independent variable because according to Becker (1971), banks primarily discriminate in three ways: (a) by applying higher interest rates for loans requested by woman entrepreneurs; (b) by imposing heavier pre-contractual conditions on female firms than male firms; (c) by demanding higher creditworthiness from female entrepreneurs than from their male counterparts before granting them loans. 
This study aims to observe whether the factors can affect the loan granted in peer-to-peer lending in Indonesia. The factors examined in this study were loan amount, loan period, interest rate, gender, and loan history using data from peer-to-peer lenders registered and supervised by the Otoritas Jasa Keuangan [Financial Services Authority] (OJK) in November 2019.

\section{HYPOTHESES}

\subsection{Loan amount}

Zhang et al. (2017) state that the higher the loan amount, the lower the loan rate is granted in peerto-peer lending transactions. This is in line with research by Mach et al. (2014), Kgoroeadira et al. (2019), and Nowak et al. (2018), which states that the higher the loan amount, the lower the probability of a loan being granted. This logic leads to the following hypothesis:

H1a: There is a negative relationship between loan amount and loan granted from peer-to-peer lending.

\subsection{Loan period}

Based on Zhang's research (2017), the shorter the loan repayment period, the higher the probability of the loan being granted. The longer the repayment period, the higher the lender's investment interest in the loan. These considerations give rise to the following hypothesis:

H2a: There is a negative relationship between loan period and loan granted from peer-to-peer lending.

\subsection{Interest rate}

Zhang et al. (2017) and Nowak et al. (2018) show that the higher the interest rates offered, the higher the likelihood that a loan will be granted. The hypothesis built on this variable is as follows:

H3a: There is a positive relationship between interest rate and loan granted from peer-topeer lending.

\subsection{Gender}

The hypothesis formed by Zhang et al. (2017) on this variable is that gender influences whether a loan is granted. In this hypothesis, the variables are divided into two: male and female. The hypothesis formed from these assumptions is as follows:

H4a: There is an influence of gender on loan granted from peer-to-peer lending.

\subsection{Loan history}

Zhang et al. (2017), Mach et al. (2014), and Nowak et al. (2018) build the hypothesis that loan history or credit history influences granted loans. Besides, loan history influences the creditworthiness of a loan. A significant loan history means that the borrower has a high creditworthiness. Loan history is divided into two categories: already borrowed before or borrowing for the first time. Therefore, the hypothesis built in this study is as follows:

H5a: There is an influence of loan history on loan granted from peer-to-peer lending.

\section{METHODS}

The research analysis model used to analyze the variables in this study (Asnawi \& Wijaya, 2006; Zhang et al., 2017) is presented in Figure 1.

Based on the analysis model, the dependent variable and the independent variable are structured to find the factors influenced funded loans (see Figure 1). All of the variables are categorical variables, in which a categorical variable has values that can put into a countable number of distinct groups based on a characteristic. Table 1 presents a description of the variables in this study.

Table 1. Description of variables

\begin{tabular}{c:c}
\hline \multicolumn{1}{c}{ Variables } & \multicolumn{1}{c}{ Description } \\
\hline Loans granted & $\begin{array}{l}\text { Loans are 100\% granted from peer-to-peer } \\
\text { lending }\end{array}$ \\
\hdashline Loan amount & Number of borrower loans \\
\hdashline Loan period & Number of days of the loan contract \\
\hline Interest rate & Percentage of the specified interest rate \\
\hdashline Gender & Gender of the borrower \\
\hline Loan history & $\begin{array}{l}\text { Has the borrower ever lent to peer-to-peer } \\
\text { lending }\end{array}$ \\
\hline
\end{tabular}




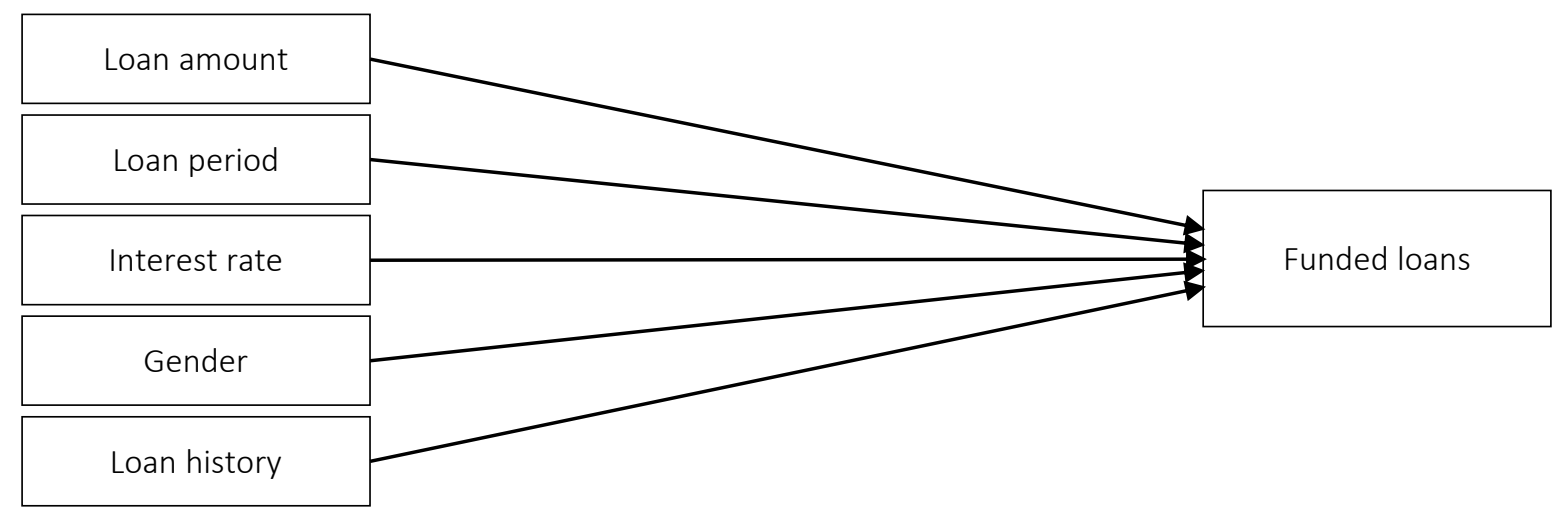

Figure 1. Research analysis model

Based on theory, problems, phenomena, and previous research, the researcher is interested in examining the influence of loan granted factors on peer-to-peer lending in Indonesia. These factors include loan amount, loan period, interest rate, gender, and loan history (see Table 1). This is intended to reduce the risk of default from borrowers on the platform or investors. This study hypothesizes that there is an influence of loan amount, loan period, interest rate, gender, and loan history on loan funded (peer-to-peer lending) in Indonesia.

Using 1,006 loan applications obtained from the registered peer-to-peer lending marketplace that has a license in the Financial Services Authority in November 2019, loans granted, loan amount, loan period, interest rate, gender, and loan history are observed. The panel data used in this study are cross-sectional to examine several variables over multiple periods. Whether loans are loan (amount) granted, a ratio of amount request is used as the dependent variable, and the independent variables include the loan amount, loan period, interest rate, gender, and loan history. Gender is important to be considered as an independent variable because, according to Becker (1971), banks primarily discriminate in three ways: (a) by applying higher interest rates for loans requested by woman entrepreneurs; (b) by imposing heavier pre-contractual conditions on female firms than male firms; (c) by demanding higher creditworthiness from female entrepreneurs than from their male counterparts before granting them loans.

Over the study period, peer-to-peer lending lent about IDR 59 billion with interest rate varying from $2.3 \%$ to $20 \%$. Loan period varies from 7 days to 365 days. There were 549 (54.6\%) male borrowers and 457 (45.4\%) female borrowers in this study. The data show that 824 (81.9\%) borrowers have borrowed before.

Binary logistic regression is used when dependent variables only use two values, such as yes or no, or 1 or 0 (Hosmer \& Lemeshow, 1989). The logistic regression approach explains the relationship between $\mathrm{x}$ and $\pi(\mathrm{x})$ having nonlinear properties, an irregular Y distribution, and the variation of unstable and constant responses that cannot be explained by linear regression analysis (Agresti, 1990). The empirical model in this study can be written as follows:

$$
\begin{aligned}
& \text { Granted loan }=\beta_{0}+\beta_{1} \text { Loan amount }+ \\
& +\beta_{2} \text { Loan period }+\beta_{3} \text { Interest rate }+ \\
& +\beta_{4} \text { Gender }+\beta_{5} \text { Loan history }+e .
\end{aligned}
$$

\section{RESULTS}

This study conducted a model fit test of the regression analysis method to predict loans granted on loan applications in a peer-to-peer lending platform registered and licensed in the November 2019 marketplace. HosmerLemsehow goodness-of-fit test is used to test whether the model are fit. The results show Hosmer-Lemeshow goodness-of-fit test have values of 0.206 , which is above 0.05 , showing that the model is said to be fit. Besides, the log-likelihood test shows that the Chi-square count is lower than the Chi-square table, indicating that the independent variable's inclusion influences whether the loan is granted. 
Table 2. Accuracy of the logistic regression model

\begin{tabular}{|c|c|c|c|c|}
\hline & \multirow{3}{*}{ Observed } & \multicolumn{3}{|c|}{ Predicted } \\
\hline & & \multicolumn{2}{|c|}{ Granted } & \multirow{2}{*}{ Percentage correct } \\
\hline & & Not fully granted & Fully granted & \\
\hline \multirow{2}{*}{ Granted } & Not fully granted & 28 & 22 & 56.0 \\
\hline & Fully granted & 8 & 948 & 99.2 \\
\hline \multicolumn{2}{|c|}{ Overall percentage } & & & 97.0 \\
\hline
\end{tabular}

Next, the binary logistic regression model was used to predict loan funding. Table 2 reports the prediction results and accuracy. Among the application set, 956 applications obtained the loan, and 50 failed. The total prediction accuracy is $97 \%$ (see Table 2), which indicates that the logistic regression model has high predictive accuracy in this research.

Table 2 shows the distribution of the total accuracy of the logistic regression model and not the matrix. The table shows that the level of accuracy in this study is very high. Binary logistic regression test results showed that three of the five variables had a significant influence, with a level of the Nagelkerke R-squared of $60.5 \%$. In sum, loan amount, loan period, and loan history significantly influence whether a loan is granted on a peer-topeer lending platform.

Other variables can explain whether a loan is granted on a peer-to-peer lending platform. The value can still be increased if some other data are available on the peer-to-peer lending platform and the Financial Services Authority. However, currently, the data provided is limited, so the $\mathrm{R}$-squared figure is $60.5 \%$. There are many possibilities for further research due to $39.5 \%$ of undiscovered variables. Over time, peer-to-peer lending platforms must analyze more variables to improve the quality of loans to be offered to potential lenders. The government should be able to authorize peer-to-peer lending platforms to analyze these undiscovered variables. These variables are useful for peer-to-peer lending platforms and advanced researchers in this field.

Based on SPSS output for the binary logistic regression in Table 3, which is statistically significant at probability $0.000<0.05$, there are several implications obtained (1) Using data sample, higher amount of loan have significant influence on certain loan granted (2) The loan period significantly associated with loan granted, the shorther loan period giving more likelihood that the loan will be granted (3) The loans interest rate has not significant impact on the loan granted (4) Whether it is male or female, it is not significant to loan granted (5) Borrowers with a history of paying off their loans has a significant effect on loan granted. Nagelkerke R-squared value is $60.5 \%$, which means loan funding is influenced by independent variables (loan amount, loan period, loan history) by $60.5 \%$. Other variables outside this study influence the rest.

\section{DISCUSSION}

This study shows that the loan amount influences whether a loan is granted. Moreover, this research indicates that the higher the loan, the lower the possibility to be granted, and vice versa. The amount of the loan influences decisions of lenders whether to lend funds. Also, lenders do not have sufficient funds to meet the borrowers' loans due to high loan amounts. Most loans that are not granted have a high value, in this study ranging from IDR

Table 3. The results of data processing for hypotheses testing with SPSS

\begin{tabular}{|c|c|c|c|c|c|c|}
\hline Variables & B & S.E. & Wald & df & Sig. & $\operatorname{Exp}(B)$ \\
\hline Loan_amount & -.180 & .000 & 68.807 & 1 & .000 & 1.000 \\
\hline Loan_period & -.006 & .003 & 6.244 & 1 & .012 & .994 \\
\hline Interest_rate & .113 & .077 & 2.258 & 1 & .133 & .891 \\
\hline Gender & .000 & .450 & .159 & 1 & .690 & .836 \\
\hline Loan_history & .000 & .494 & 4.483 & 1 & .034 & .351 \\
\hline Constant & 6.292 & 1.200 & 27.498 & 1 & .000 & 540.327 \\
\hline
\end{tabular}


$100,000,000$ to IDR 500,000,000. Meanwhile, the average loan amount granted is IDR 29,064,984, with an increase of $63.7 \%$ year-to-date. The increasing number of lenders affects increasing the average loan amount granted, yet loans are currently still not covering high loan amounts.

The results also show that the loan period has an impact on whether a loan is granted. Lenders provide loans to borrowers with the hope of quick and timely repayments. Loan periods vary between 7 to 365 days of repayment. The average loan period is 45 days. Peer-to-peer lending provides a shorter lending repayment period than others, such as sovereign debt with a minimum 1-year repayment rate and shorter repayment rates loan funding in peerto-peer lending.

A high interest rate will certainly attract lenders to provide funds. Interestingly, the interest rate has no significance on whether a loan is granted in this study. From the observed data, despite providing a high interest rate, loans are still not granted. Due to higher non-performing peer-to-peer lending than banks, lenders may prioritize the certainty of repayment not to risk their funds on loans with steep interest rates. Lenders tend to pay more attention to variables showing the certainty of loan repayment.

Loan history shows the credibility of the borrower to repay the loan. Borrowers who have returned their loans will certainly increase the lender's confidence in providing their loans. Lenders anticipate that the borrower will return the loan and interest as before. Meanwhile, gender is not a significant factor influencing whether the loan is approved. At this time, gender has not described borrowers' credibility due to the lack of further information, such as the number of dependents and other significant factors. This result shows that lenders tend to provide funds to borrowers who have already shown credibility to repay the loan. This risk aversion from lenders may arise from the knowledge that peer-to-peer lending has higher non-performing loan rate (3.65\%) than banks (2.73\%).

This study's new insight is that despite those limited variables, total peer-to-peer lending loan amount reached 27 trillion rupiahs, or $141 \%$, over six months from December 2018 to July 2019. With a proper loan and borrowers' information, lenders can receive better information quality to decide whether to lend their funds. Furthermore, these results focused on which information has the strongest effect on the loan funding process. Loan amount, loan period, and loan history are seen as important aspects of loan funding decisions. In conclusion, as the information affects loan funding, distributed funds through peer-to-peer lending will be higher by presenting more information to lenders and potential lenders.

\section{CONCLUSION}

This study analyzes the factors that affect loan funding on peer-to-peer lending registered and authorized in Otoritas Jasa Keuangan [Financial Services Authority] during November 2019. The funding probability is modeled using a binary legalistic regression. The results show that loan amount, loan period, and loan history simultaneously significantly affect the loan funding process. Loan amount and loan history have a negative and significant effect on loan funding, and loan period also has a significant effect on loan granted. However, interest rate and gender have no positive and significant effect on peerto-peer lending and loan funding.

As a result, compared to loan amount and loan period, lenders tend to lend their funds on the lower loan amount and shorter loan period than the high loan amount and longer loan period. Borrowers loan history represent borrower credibility based on prior loan followed by punctual loan return and interest payment. This research shows lenders trust the borrower who has loan history rather than borrowers without a prior loan. Peer-to-peer lending platform can take the opportunity to review and ensure the appropriate loan selection in improving the quality of loans offered. The result implies that lenders who want to raise their fund in peer-to-peer lending need to pay more attention to their loan characteristics, such as loan amount, loan period, and loan history are the determinants of loan funding in this market. 


\section{AUTHOR CONTRIBUTIONS}

Conceptualization: Chandra Wijaya, Fajri Kurniawan.

Data curation: Fajri Kurniawan.

Formal analysis: Fajri Kurniawan.

Funding acquisition: Chandra Wijaya.

Investigation: Chandra Wijaya, Fajri Kurniawan.

Methodology: Chandra Wijaya, Fajri Kurniawan.

Project administration: Chandra Wijaya, Fajri Kurniawan.

Resources: Fajri Kurniawan.

Software: Fajri Kurniawan.

Supervision: Chandra Wijaya, Fajri Kurniawan.

Validation: Chandra Wijaya, Fajri Kurniawan.

Visualization: Fajri Kurniawan.

Writing - original draft: Fajri Kurniawan.

Writing - review \& editing: Chandra Wijaya, Fajri Kurniawan.

\section{REFERENCES}

1. Agresti, A. (1990). Categorical Data Analysis. John Wiley and Sons, Inc.

2. Asnawi, S. K., \& Wijaya, C. (2005). Riset Keuangan: PengujianPengujian Empiris (Financial Research: Empirical Testing). Gramedia Pustaka Utama, 274.

3. Asnawi, S. K., \& Wijaya, C. (2006). Metodologi Penelitian Keuangan: Prosedur, Ide, dan Kontrol (Financial Research Methodology: Procedures, Ideas, and Control). Graha Ilmu.

4. Bachmann, A., Becker, A. Buerckner, D., Hilker, M., Kock, F., Lehmann, M., Tiburtius, P., \& Funk, B. (2011). Online Peer-toPeer Lending - A literature review. Journal of Internet Banking and Commerce, 16(2), 2-18. Retrieved from https://www.researchgate. net/publication/288764128_Online_Peer-to-Peer_Lending_A_Literature_Review

5. Becker, G. S. (1971). The economics of discrimination. University of Chicago Press.

6. Crosson, S. V., \& Needles, B. E. (2008). Managerial Accounting (8th ed). Houghton Mifflin Company.

7. Edelberg, W. (2006). Riskbased pricing of interest rates for consumer loans. Journal of
Monetary Economics, 5(8), 2283 2298. Retrieved from https:// ideas.repec.org/a/eee/moneco/ v53y2006i8p2283-2298.html

8. Fabozzi, F. (2006). Bank loans: Secondary Market And Portfolio Management. Frank J. Fabozzi Associates. Retrieved from https:// www.wiley.com/en-us/Bank+L oans $\% 3 \mathrm{~A}+$ Secondary+Market +and+Portfolio+Managementp-9781883249441

9. Hosmer, D. W., \& Lemeshow, S. (1989). Applied logistic regression. John Wiley and Sons.

10. Kgoroeadira, R., Burke, A., \& van Stel, A. (2019). Small business online loan crowdfunding: Who gets granted and what determines the rate of interest? Small Business Economics, 52(1), 67-87. https:// doi.org/10.1007/s11187-0179986-Z

11. Kim, Y. H., Park, Y., \& Choi, J. (2016). The Adoption of Mobile Payment Service for Fintech. Research India Publication, 11(2), 1058-1061. Retrieved from https:// www.researchgate.net/publication/298714824_The_adoption_of_mobile_payment_services_for_fintech

12. Lin, M., Prabhala, N. R., \& Viswanathan, S. (2013). Judging borrowers by the company they keep: Friendship networks and information asymmetry in online peer-to-peer lending. Management Science, 59(1), 17-35. https://doi. org/10.1287/mnsc. 1120.1560

13. Lin, X., Li, X., \& Zheng, Z. (2017) Evaluating borrower's default risk in peer-to-peer lending: evidence from a lending platform in China. Applied Economics, 49(35), 35383545. https://doi.org/10.1080/0003 6846.2016.1262526

14. Mach, T. L., Cartwe, C. M., \& Slattery, C R. (2014). Peer-topeer lending to small businesses. Finance and Economics Discussion Series Division of Research and Statistics and Monetary Affairs, Federal Reserve Board, Washington D.C. Retrieved from https:// www.federalreserve.gov/pubs/ feds/2014/201410/201410pap.pdf

15. Merton, R. C. (1974). On the pricing of corporate debt: The risk structure of interest rates. The Journal of Finance, 29(2), 449-470. Retrieved from https://www.jstor. org/stable/2978814?seq=1

16. Napitupulu, S. K., Rubini, A. F., Khasanah, K., \& Rachmawati, A. D. (2017). Perlindungan Konsumen pada Fintech Kajian Perlindungan Konsumen Sektor Jasa Keuangan (Consumer Protection in Fintech Review of Consumer Protection in the Financial Services 
Sector). Otoritas Jasa Keuangan. Jakarta.

17. Nowak, A., Ross, A., \& Yencha, C. (2018). Small Business Borrowing and Peer-To-Peer Lending: Evidence from Lending Club. Contemporary Economic Policy, 36(2), 318-336. https://doi. org/10.1111/coep.12252

18. Omarini, A. E. (2018). Peer-toPeer Lending: Business Model Analysis and the Platform Dilemma. International Journal of Finance, Economics and Trade, 2(3), 31-41. Retrieved from https:// scidoc.org/IJFET-02-301.php
19. Otoritas Jasa Keuangan. (2019, July). Statistik: Fintech Lending. Retrieved from https://www.ojk, go.id/id/kanal/iknb/data-danstatistik/fintech/Pages/StatistikFintech-Lending-Periode-Juli-2019.aspx

20. Priskarini, I. A., Pranoto, \& Tejomurti, K. (2020). The Role of Financial Services Authority in The Legal Protection of Privacy Rights in Connection with Personal Data of Fintech Lending Debtor in Indonesia. PJIH, 6(3), 556. Retrieved from http:// jurnal.unpad.ac.id/pjih/article/ view/24748
21. Suiter, W. O., \& Thomas, R. G. (1938). Modern Banking. Southern Economic Journal, 5(1), 102. https://doi. org/10.2307/3693817

22. West, C., \& Zimmerman, D. H. (1987). Doing gender. Gender and Society, 1(2), 125-151. https://doi. org/10.1177/0891243287001002 002

23. Zhang, Y., Li, H., Hai, M., Li, J., \& Li, A. (2017). Determinants of loan granted successful in online P2P lending. Procedia Computer Science, 122, 896-901. https://doi. org/10.1016/j.procs.2017.11.452 